\title{
OLD, POOR AND OUT ON THE STREETS: ON THE ROAD TO EXCLUSI ON
}

\author{
Flávia Saraiva Leão Fernandes ${ }^{1}$ \\ Milena Veiga Raizer² \\ Ana Cristina Passarella Brêtas ${ }^{3}$
}

Fernandes FSL, Raizer MV, Brêtas ACP. Old, poor and out on the streets: on the road to exclusion. Rev Latinoam Enfermagem 2007 setembro-outubro; 15(número especial):755-61.

This exploratory study aimed to investigate and describe the homeless elderly population user of a shelter specifically designed for them in Sao Paulo. A total of 20 elderly participated in the study. The data were gathered through interviews and field observation. The data analysis was based on Collective Health and Gerontology references. The main results reveal that the vulnerability of the elderly to become homeless occurs in a macro level, characterized by fragile work and residence ties. The micro level is characterized by the lack of familiar support. In conclusion, this study led us to rethink the human values regarding the social inequalities as well the trivialization of social injustice. We learned to view the homeless elderly as subject and not just passive object of charity and assistance.

DESCRIPTORES: aged; homeless; health; public health; poverty

\section{POBRE, ANCI ANO Y EN LA CALLE: UNA TRAYECTORI A DE EXCLUSI ÓN}

Este estudio exploratorio tiene por objetivo investigar y describir la población anciana que vive en las calles, usuaria de un abrigo exclusivo para este segmento social en la ciudad de Sao Paulo. Los sujetos estudiados fueron veinte ancianos. Los datos fueron recolectados mediante técnicas de entrevista y observación de campo. Estas informaciones fueron analizadas mediante referenciales de las áreas de Gerontología y Salud Colectiva. Los principales resultados muestran que la vulnerabilidad del anciano en la calle ocurre tanto en el nivel macro, caracterizado por lazos de cuestiones laborales y habitacionales frágiles, como en el nivel micro, caracterizado por la falta de apoyo familiar. En conclusión, este estudio llevó a repensar los valores humanos respecto a desigualdades sociales y canalización de la injusticia social. Aprendimos a ver al anciano que vive en la calle como sujeto y no objeto pasivo de caridad y asistencialismo.

DESCRIPTORES: anciano; personas sin hogar; salud; salud pública; pobreza

\section{POBRE, I DOSO E NA RUA: UMA TRAJ ETÓRI A DE EXCLUSÃO}

Este estudo exploratório teve por objetivo investigar e descrever a população idosa em situação de rua, usuária de um abrigo exclusivo para esse segmento, na cidade de São Paulo. Os sujeitos do estudo foram 20 idosos. Os dados foram coletados por meio das técnicas da entrevista e observação de campo. Foram analisados à luz dos referenciais das áreas da Gerontologia e Saúde Coletiva. Os principais resultados mostram que a vulnerabilidade do idoso às ruas se dá tanto no nível macro, caracterizado por laços trabalhistas e habitacionais frágeis, quanto no nível micro, caracterizado pela falta de apoio familiar. Concluindo, esse estudo propocia a reflexão sobre os valores humanos no que diz respeito às desigualdades sociais e banalização da injustiça social. Aprende-se a ver o idoso de rua como sujeito e não um objeto passivo de caridade e assistencialismo.

DESCRITORES: idoso; sem teto; saúde; saúde pública; pobreza

\footnotetext{
${ }^{1}$ Undergraduate Student, schorlarship for scientific initiation PIBIC/CNPq/UNIFESP 2005-2007, e-mail: flaviasIf@gmail.com; ${ }^{2}$ Undergraduate Student, email: miveigaraizer@bol.com.br; ${ }^{3}$ Advisor, RN, Sanitarist, Adjunct Professor. Department of Nursing, São Paulo Federal University, Brazil, e-mail acbretas@denf.epm.br
} 


\section{NTRODUCTION}

I n October 2003, the President of Brazil passed Law number 10741, which concerns the Elderly Statute and presents other measures ${ }^{(1)}$. It should be emphasized that it took long years of procedures and discussions in the National Congress and required a broad mobilization of elderly and technicians committed to the cause of aging. Not only does it consolidate the rights ensured in other legislations, including the National Elderly Policy ${ }^{(2)}$, the National Elderly Health Policy ${ }^{(3)}$ and the Single Health System ${ }^{(4)}$, but it also broadens, enhances and defines protection measures for people aged 60 years or more.

The Elderly Statute ${ }^{(1)}$ considers life and aging as individual and social rights. It demands the State to guarantee elderly people with the protection of life and health through the implementation of public social policies that ensure healthy and dignified aging. However, elderly often live in a situation of extreme poverty, deprived of such protection that would ensure the maintenance of their basic health necessities. Moreover, it is constantly observed that the Public Power and society lack preparation to meet the legal precepts.

This study is based on the belief that public policies, in the social domain, are instruments capable not only of assessing poverty, but, above all, of redefining access to opportunity. In this sense, the authors present the issue of aging on the streets, with a view to accentuating the difference between charity and justice in complying with legislation.

In Sao Paulo, the City Council passed Law number $1232 / 97$, which determines on care to people on the streets. Despite being assistentialist, it aims, insofar as possible, to ensure constitutional rights that seek to guarantee equality among Brazilians. The Law determines services and programs for this population, aiming to provide them at least with care for their absolute poverty situation.

In 2003, the Fundação Instituto de Pesquisas Econômicas (FIPE) [Economic Research Institute Foundation], by request of the Secretaria de Assistência Social (SAS) [Social Care Secretariat], carried out a census of people living on the streets in Sao Paulo, registering 10,394 people - 6,186 of whom were located in the streets and 4,208 in shelters ${ }^{(5)}$.

Aging is a natural phenomenon. Hence, all being get old, since their bodies are finite. The idea of finitude in life is given by the vicissitudes of the body and should be part of human existence. However, not everyone notices and/or accepts aging.

The aging process includes, but is not limited to, the old age phase. Life and aging qualities relate with the individual's view of the world and society he or she lives in. Therefore, aging is not only a biological phenomenon, but, above all, the convergence of socially constructed factors, which assign a different status to aging people ${ }^{(6)}$. This assertion is essential when working with elderly living on the street.

In this discussion, the authors introduce the precept that there are different forms of aging and, thus, old age. The place individuals hold in society affects the way they obtain conditions to manage their personal care. This fact suggests that social injustice affects this care relationship, and, therefore, cannot be disregarded when analyzing the object of this study.

The current social conjecture has points in common with a war situation. However, it does not refer to an armed conflict, but to an "economic war". Its setting is the job market and world, in which people who are not ready for combat are harmed because they are not able to achieve the productivity, availability, discipline, and abnegation imposed by the economic system. People excluded from the job market comprise the reserve army - elderly who do not have the agility of younger individuals, young individuals who do not have the experience of older ones, and those without access to information and education $^{(7)}$. From this perspective, the authors include in the discussion elderly living on the streets, who are doubly excluded since they are both old and poor. Therefore, the purpose of this study is to investigate and describe the elderly population living on the streets, at a shelter exclusive for elderly in Sao Paulo.

\section{METHOD}

This is an exploratory study, since it was developed to provide more familiarity with the study object $^{(8)}$, offering an overall view regarding old age on the streets. This choice was made due to the scarcity of studies on this theme. It aims to deepen knowledge about aging on the streets in order to support other studies at the Center for Health Studies and Research, Public Policies and Social Movements at Sao Paulo Federal University (Unifesp). The study was approved by the Unifesp review board (CEP: 0835/04). 
Study subjects were elderly men and women, aged 60 years or more, users of the shelter, conscious and apt to maintain a dialogue. Twenty elderly (eight men and 12 women) took part in this study. All subjects met the requirements and agreed to participate in the research after being informed about the object, objectives, method and form of diffusion. Participants provided written consent.

Data was collected using interview and observation techniques, by administrating an instrument and keeping a field diary. Simple frequency distribution analysis was used and the data was analyzed by means of interpretative reading ${ }^{(8)}$, in the light of selected theoretical-conceptual references in Gerontology and Collective Health.

\section{RESULTS AND DI SCUSSI ON}

The scarcity of sociodemographic studies, published over the last decades, capable of outlining a setting about the profile of the Sao Paulo street population impedes the correlation with this study's findings. However, subjective data, based on field observation and conversations with professionals working with this population, suggest that this segment has grown older.

According to a study performed by the Municipal Secretariat for Social Development ${ }^{(9)}$ in 621 shelters, there is a tendency towards shelter population aging: in the year $2000,12.7 \%$ of that population were aged 55 years or more; in 2003, $19.9 \%$; and the present study, carried out in 2006, observed that the elderly population represents $23.1 \%$. While the average sheltered adults' age was 41.2 years in the year 2000 , today it is 44.7 years.

The overall Brazilian population's aging, like in the rest of the world, has deserved many sorts of analyses and justifications for its process. However, as mentioned before, due to the few studies in this area, it is difficult to explain this phenomenon for a street population. It is not known why the street population has aged, neither what happens with them afterward.

The increase in the number of elderly on the streets has been the research goal of a study performed in San Francisco, USA, which analyzed the local street population's tendency to aging. In that region, the average age of people living on the street increased from 37 to 46 years over a 14-year period, between 1990 and 2004. A similar fact was found in other five North American cities.

This aging phenomenon on the streets is repeated in Sao Paulo, which suggests that the increase in the street people's average age has risen in overall capitalist societies. Adults are now elderly, and their chances of social reinsertion are gradually reduced.

Little is known about what happens with the street population after they age. In spite of the shelter - the place of research - being for people aged over 60 years, the authors did not find any elderly aged over 70. There is no explanation for this fact. However, hypotheses may be raised. Individuals might be willing to live on the street. Most are wanderers, searching for food, shelter and protection. Once they lose their physical ability to move around the city, survival strategies are armed. Hence the study's question: do they die, or are they welcomed by any entity, some kind of long-stay institution for instance?

Regarding origin, the SMADS detected that a small part of sheltered adults are actually from the capital; most are from the Northeast and Southeast ${ }^{(9)}$. In the studied shelter, it was verified that nine elders are from the Northeast, ten from the Southeast, and only two were born in Sao Paulo.

Sixteen elderly have lived in this city for over 20 years. This suggests that they would have established affective attachments or some kind of social support network in the city. However, the only type of social support identified was institutional: the shelter. Throughout the lives of the street population, there is a rupture with family ties, an abandonment of roles that involve responsibilities and affectivity. This is reflected in the infirmity of the affective ties they establish on the streets. When family breakage/ rupture exists, institutional dependence is evidenced $^{(11)}$. That dependence, characterized by the use of support services, could encourage this population to remain on the streets. These projects are essential for the street population's survival. However, they could also have a negative influence on the social (re)insertion process, contributing to the lack of encouragement for them to search for autonomy. Hence, instead of preparing them and giving them the tools to recover their citizenship, they are impeded from developing the autonomy needed to break dependence ties and get off the streets $^{(12)}$. 
Considering that families are primary socialization agents and serve as a support network during crises, their absence could imply serious consequences. Family support is inexistent for the majority of the street population ${ }^{(13)}$. Therefore, breaking with family ties in addition to breaking with work ties is considered "point zero" in the process for becoming a street person. This is especially true for the Brazilian society, in which family unity is the support for the poor working-class social relationships, so, its absence can be a determining factor in this process $^{(11)}$. This fact can be observed since, in this study, it was found that 12 participants had relatives in Sao Paulo, but only three kept in touch with them frequently. Eleven participants had relatives out of town, and only one kept in touch. Five participants reported that family breakage was the reason for their moving onto the streets. In addition, despite the other participants not considering lack of family support a limiting factor to move onto the streets, it was present in other statements.

Two groups of factors interact when considering the reasons for which people move onto the streets. First, there are the broad, structural tendencies at macro level; and, second, there are biographical factors, i.e., at individual level ${ }^{(13)}$. For the study population, the individual factor was identified as the lack of family support, as mentioned before.

Regarding the macro level, it was not possible to establish a direct relationship between unemployment, fragility of work ties, and living on the streets. However, unemployment is reported in many life history statements as the reason for moving onto the streets ${ }^{(11,13)}$. From this perspective, people's vulnerability in the face of the work market becomes evident, since eight participants moved onto the streets due to financial problems, including unemployment.

The vulnerability of work ties, before moving into the streets, is also evident. It is characterized by having low or no specific qualification. This imposes fragile occupational identities on the population, characterized by activities with a high potential of replacement and with a borderline income for survival levels ${ }^{(11)}$.

Such vulnerability was identified in the present study when it was found that most participants, 18 elderly, had worked in more than one remunerated activity that did not require any specific qualification; most in the commercial and service sector, such as housekeeping and electricians.
The same standard was observed in activities currently performed by the street population, when they do work. Among the currently and formerly working adults and elderly, $96 \%$ do not have any formal work register ${ }^{(9)}$. In the study, five of the 20 participants worked in the informal market, with no formal register. However, 14 participants reported the need and desire to work. Besides providing physical subsistence, working assigns professional identity, which is part of one's personal identity. In the current society, in the capitalist system, professional identity is overestimated. Individuals are recognized by their profession. Therefore, lacking such a profession or any other drawback to the individual's insertion in the work market poses stigmatizations and feelings of guilt, which is quite common among the street population $^{(15)}$

The capitalist culture is also observed in the statements of street population involved in work founded on solidary economy. Cooperativism was difficult to implement and not well accepted among the street population of a non-governmental organization (NGO) in Sao Paulo. Street people perceive work and income generation through cooperative as temporary activities, from which they would move away as soon as they got a job. The perspective of being employed, selling their work power, was greater than generating income through the cooperative. This shows the recognition of employment as the only desired form of work ${ }^{(12)}$.

In this study, the studied population is extremely vulnerable financially and depends on governmental support. Social security/promotion support is the income source for eight participants, other eight do not have any income, and count exclusively on the shelter for their physiological, welcoming and protection needs.

In addition to the difficulty of insertion in the work market, there is the housing vulnerability that affects society as a whole, particularly poorer Brazilians. This problem is aggravated in the case of underqualified populations with fragile ties with the work market, increasing the possibility of moving onto the streets. In this perspective, this study found five elderly who reported eviction as the cause for their moving onto the streets.

Early insertion in the work market and low education level are factors that influence vulnerability in terms work and/or housing ties ${ }^{(14)}$. Regarding the studied population, two participants were illiterate, 
eight had complete primary education, six had incomplete primary education, and two had complete secondary education.

Moreover, it was surprising that, in the studied population, there was one lawyer and one teacher. This led to a reflection about the relationship between educational level and social vulnerability. Education is an individual asset. However, it cannot be considered a guarantee of social security. Since the study found professionals with superior education living in shelters and on the streets, the authors reconsider the value of a university diploma.

Diplomas may facilitate stable and formal work relationships, but would it maintain individuals in this condition and prevent the risk of unemployment, financial difficulties, and of moving onto the streets in this contemporaneous context of structural unemployment? In this sense, it is safe to affirm that the individual's vulnerability of being exposed to the streets results from the interference of a group of individual, collective, social and contextual factors, rather than from one single factor. However, it should be investigated if this fact is recent or not, since studies have shown that the educational level among sheltered individuals is higher among younger adults (under 30 years if age). Of these, $33 \%$ had started secondary education $^{(9)}$.

It was observed that elderly with less time in the shelter are more critical about their situation. The authors believe that there is a direct relationship between the satisfaction that individuals assign to their life condition and their expectations in this respect. In other words, the closer one gets to his or her expectations, the more satisfied one gets. Knowledge increases and multiplies people's desires, and the less they desire, the easier it is to have their needs fulfilled.

As far as health is concerned, the shelter is part of the Community Street Health Agents Program at the Sao Paulo Municipal Health Secretariat. Therefore, elderly living at the shelter have access to Basic Health Units (BHU), without any trouble to schedule appointments. Six participants have high blood pressure and three have diabetes mellitus, all of whom are periodically followed-up at the BHU.

When asked about health problems, none of the participants reported having any chronic disease. Some acute factors were reported, including flu, headache; pneumonia, and other health problems, such as two cases of run-over. It was observed that, for participants, health problems refer to something that makes them immediately seek health services - Emergency Room and/or the $\mathrm{BHU}$. This suggests that chronic diseases do not make participants feel ill.

Considering that being healthy and becoming ill are exclusive, individual experiences, as well as forms of life expressions ${ }^{(16)}$, it becomes easier to understand the answers obtained. These answers cannot be analyzed by means of the WHO definition complete biopsychosocial wellbeing - since it would be noticed that no one is healthy; it would become an utopia. If health were not considered as the mere absence of illness, nor as complete wellbeing or total normality, but as a moderate amount of suffering, with prevalence of wellbeing feeling, it would become an ideal, but also a reality ${ }^{(17)}$.

Disease is not the mere disappearance of a physiologic function, but the appearance of a new vital order. Health is a state of functional harmony and balance, both physical and psychological, considering one's natural and social environment. This balance and harmony are capable of adapting the organism when submitted to new environmental conditions, either natural or social ${ }^{(18)}$.

Considering that the organism has norms that permits it to adapt to the environment, being healthy is not only being normal in a certain situation, but in various. On the other hand, disease cannot be considered as the absence of a norm. Actually, it is a life norm that is not capable of adapting the organism to the environmental conditions which it is inserted $\mathrm{in}^{(18)}$. Human beings do not feel wellbeing because it is the conscience of living, it is the impediment to spend the life that is felt and recognized. Hypertensive and diabetic street people do not consider themselves ill, since they have adapted to the new norm imposed by their bodies, and do not feel their wellbeing.

Another category that emerged during data analysis concerns the time living on the streets. In this respect, the referenced used was a typology founded on street people, approaching categories such as the "newly-dislocated", characterized by people who are afraid of street company, do not know who to trust and if they will survive. The newlydislocated usually turn to care institutions where they receive food and shelter. They recall their memories with happiness and a strong desire to return to the 
former condition. In addition to their plans of leaving, their behaviors are rationally directed towards that goal; they are the ones who most look for jobs. They deny the social identity of a street person and emphasize that they are not like their street friends ${ }^{(13)}$.

Based on the study population's statements, they can be considered newly-dislocated, since they have not experienced living on the streets; they are all sheltered with little or no time on the streets. The shelter was the first institution for eight elderly, and seven had been in only one shelter before. Seventeen participants reported that, less than three years ago, they had a house to live in, which illustrated the short period in that situation. Many still plan to leave the shelter, and still look for a job.

The street population is defined as the segment of extremely low income that, temporarily or permanently, spends nights on the city streets, and in public or social entity shelters ${ }^{(19)}$. This definition brings about a reflection about the apparent homogenization of this population, since it places individuals living on the streets and those living in shelters in the same segment. In the case of the study population, it is not known if it can be considered as people living on the streets, since they have not exactly lived this specific experience.

The authors believe that this affects the constitution of a social identity, as well as the selfcare conditions and having a perspective to get out of this situation. Moving onto the streets means to develop a compensatory process regarding losses and using other survival resources, which had been ignored until this moment, and assimilate new forms of organization that permit fulfilling their needs and overcoming obstacles imposed by the city ${ }^{(20)}$. This "street culture" was not observed in the elderly.

J ust like the authors, participants did not recognize themselves as street people. In this sense, this study is being broadened to analyze the existence of differences between real street people and sheltered people. Based on the presupposition that individual health is directly related with human beings' living conditions, and is influenced by social and economic policies ${ }^{(21)}$, interventions, in the health and social area, should not have the same emphasis in different groups. Since sheltered individuals have security, shelter and hygiene conditions, those on the street have to find strategic unconventional means for their survival.

\section{FI NAL CONSI DERATI ONS}

Due to the exploratory nature of this study, no broad generalizations are possible. However, the study findings lead to reflections, though individual, about the situation of aging on the streets.

The breakage and decomposition of family and social ties are present in the life histories of the studied street population. It was observed that the fragility regarding housing and affective domains, exposure to discrimination and violence are associated with the previous vulnerabilities of this population.

In terms of the families, the studied subjects present a detachment and/or attenuation of family ties, which may be a reference from a distance. In the Brazilian context, in which the family is considered an indispensable belonging unit, not having a place means loosing family ties.

Concerning the Elderly Statute, the social protection for the studied street population is guaranteed, since they are supported by social security and/or institutional care. This does not guarantee any improvement in quality of life, since it is directly related with expectations and meanings each person attributes under the influence of his/her own beliefs and values, constructed throughout his/ her existence.

This study made the authors rethink the human values regarding inequalities and the vulgarization of social injustice. As scholars in the health area, the authors learned to see elderly living on the streets as subjects with individual characteristics and not as passive objects of charity and assistentialism. By revealing this object, the authors hope to contribute to increasing intolerance toward social injustice, which requires political action rather than charity.

The authors continue this study with new views on the qualitative perspective to understand the relationship between current thoughts in different social segments about the different meanings of being a street person. As researchers committed with the Single Health System, by understanding these differences, the authors seek to support health programs for this segment.

The authors believe that this study can add value to knowledge production in nursing, especially by introducing new indicators and views in the systemized care offered to the street population at different health services. 


\section{REFERERNCES}

1.Lei no 10.741, de 01 de outubro de 2003 (BR). Dispõe sobre Estatuto do Idoso e dá outras providências. Brasília; [Acesso em 2007 agosto 25]. Disponível em http:// www. planalto.gov. br/ccivil/LEIS/2003/L10.741.htm

2. Lei no 8.842, de 04 de janeiro de 1994 (BR). Dispõe sobre a Política Nacional do Idoso, cria o Conselho Nacional do Idoso e dá outras providências. Brasília; [Acesso em 2007 agosto 25]. Disponível em http://www. planalto.gov.br/ccivil/ LEIS/L8842.htm

3. Ministério da Saúde (BR). Política Nacional de Saúde do Idoso. Portaria 1395/GM. Brasília (DF): Ministério da Saúde; 1999.

4. Lei $n$ ㅇ 8.080, de 19 de setembro de 1990 (BR). Dispõe sobre as condições para a promoção, proteção e recuperação da saúde, a organização e o funcionamento dos serviços correspondentes e dá outras providências. Brasília; [Acesso em 2007 agosto 25]. Disponível em http:// www. planalto.gov. br/ccivil/LEIS/L8080.htm

5. Fundação Instituto de Pesquisas Econômicas. Censo dos moradores de rua na cidade de São Paulo. Relatório Executivo. São Paulo (SP): FIPE; 2003.

6. Beauvoir S. A velhice: o mais importante ensaio contemporâneo sobre as condições de vida dos idosos. Rio de Janeiro (RJ): Nova Fronteira; 1990. p.711.

7. Dejours C. A banalização da injustiça social. 3a ed. Rio de Janeiro (RJ): FGV; 2000.

8. Gil AC. Como elaborar projetos de pesquisa. 4ạed. São Paulo (SP): Atlas; 2006

9. Secretaria Municipal de Assistência e Desenvolvimento Social. Fundação Instituto de Pesquisas Econômicas. Estudos dos usuários dos albergues conveniados com a prefeitura. São Paulo (SP): SMADS/ FIPE; 2003.

10. Hahn JA, Kushel MB, Bangsberg DR, Riley E, Moss AR. The aging of the homeless population: fourteen-year trends in San Francisco. J Gen Intern Med 2006; 21:775-8.

11. Escorel S. Vidas ao léu: trajetórias de exclusão social. Rio de Janeiro (RJ): FIOCRUZ; 1999.

12. Ghirardi MG, Lopes SR, Barros DD, Galvani D. Vida na rua e cooperativismo: transitando pela produção de valores. Interface 2005 setembro-dezembro; 9(18):601-10.

13. Snow D, Anderson L. Desafortunados: um estudo sobre o povo da rua. Petrópolis (RJ): Vozes; 1998.

14. Mattos RM, Ferreira RF. O idoso em situação de rua: Sísifo revisitado. Estudos de Psicologia 2005 janeiro-março; 22(1): 23-32

15. Mattos RM, Ferreira RF. Quem vocês pensam que (elas) são? - Representações sobre as pessoas em situação de rua. Psicol Soc 2004 maio-agosto; 16(2):47-58.

16. Czeresnia D. O conceito de saúde e a diferença entre prevenção e promoção. In: Czeresnia D, Freitas CM, organizadores. Promoção da saúde: conceitos, reflexos, tendências. Rio de Janeiro (RJ): Fiocruz; 2003. p.39-53.
17. Coelho MTAD, Almeida N. Análise do conceito de saúde a partir da epistemologia de Canguilhem e Focault. In: Goldenberg P, Marsiglia RMG, Gomes MHA, organizadoras. O Clássico e o Noco: tendências, objetos e abordagens em ciências sociais e saúde. Rio de Janeiro (RJ): Fiocruz; 2003. p.101-13.

18. Canguilhem G. O normal e o patológico. 4a ed. Rio de Janeiro (RJ): Forense Universitária; 1995.

19. Fundação Instituto de Pesquisa Econômicas. Censo de moradores de rua na cidade de São Paulo. Relatório Executivo. São Paulo (SP): FIPE; 2000.

20. Varanda W, Adorno RCF. Descartáveis urbanos: discutindo a complexidade da população de rua e o desafio para políticas de saúde. Saúde \& Soci 2004 janeiro-abril; 13(1):59-9.

21. Rosa AS, Cavicchioli MGS, Brêtas ACP. O processo saúde-doença-cuidado e a população em situação de rua. Rev Latino-am Enfermagem 2005 julho-agosto; 13(4):57682. 